\title{
Hadis Tentang Wanita Menjadi Pemimpin: Menelisik Antara Pemahaman Tekstual dan Kontekstual Perspektif M. Syuhudi Ismail
}

\author{
Ummi Kalsum Hasibuan*1 dan Hafizzullah Hafizzullah² \\ ${ }^{1}$ Universitas Islam Negeri Sunan Kalijaga Yogyakarta \\ 2Institut Agama Islam Negeri Batusangkar \\ Email: ukalsumhasibuan@gmail.com
}

\begin{abstract}
This paper examines the hadith about women becoming leaders from a textual and contextual perspective M. Syuhudi Ismail. This shows that the hadith should not always be understood merely textually, but rather by paying attention to the socio-historical and context of the hadith. The purpose of this paper is to uncover and know about how the understanding of women's traditions becomes a leader in the textual and contextual review of Shuhudi. The approach used is a descriptive-analysis approach. The results of this study are: first, the textual hadith of the appointment of women as leaders is prohibited and at that time women did not have authority at all. Second, the contextual understanding of the hadith of women becoming leaders changes with time as time goes by. So that in this context Syuhudi's contextual understanding is that women may become leaders on the condition that they have authority, are able to lead and society accepts if women are leaders. In this case Syuhudi did it by looking at an analysis of asbab al-wurud and the macro context in the Persian region. Third, M. Syuhudi Ismail classifies the traditions of women into leaders as traditions related to the current situation (developing). Therefore the hadith must be understood contextually, because the contents of the hadith instructions are temporal.
\end{abstract}

Keywords: Contextual; Hadith; leader; Textual; Woman..

\begin{abstract}
Abstrak
Tulisan ini mengkaji hadis tentang wanita menjadi pemimpin yang ditinjau dari perspektif tekstual dan kontekstual M. Syuhudi Ismail. Hal ini menunjukkan bahwa hadis hendaknya tidak selalu dipahami secara tekstual semata, melainkan dengan memperhatikan sosio-historis dan konteks hadis tersebut. Tujuan tulisan ini adalah untuk menyingkap dan mengetahui tentang bagaimana pemahaman hadis wanita menjadi pemimpin dalam tinjauan tekstual dan kontekstual Syuhudi. Pendekatan yang digunakan adalah pendekatan deskriptif-analisis. Hasil penelitian dari tulisan ini adalah: pertama, sercara tekstualnya hadis pengangkatan wanita menjadi pemimpin tersebut dilarang dan ketika masa itu wanita memang sama sekali tidak mempunyai kewibawaan. Kedua, secara kontekstual pemahaman tentang hadis wanita menjadi pemimpin berubah seiring dengannya berjalannya waktu yang semakin kekinian. Sehingga dalam hal ini pemahaman kontekstual Syuhudi adalah bolehnya wanita menjadi pemimpin dengan syarat telah memiliki kewibawaan, mampu untuk memimpin dan masyarakat menerima apabila wanita sebagai pemimpin. Dalam hal ini Syuhudi melakukannya dengan melihat sebuah analisis asbab al-wurud dan konteks makro di wilayah Persia. Ketiga, M. Syuhudi Ismail mengelompokkan hadis wanita menjadi pemimpin sebagai hadis yang berkaitan dengan keadaan sedang terjadi (berkembang). Maka dari itu hadis tersebut harus dipahami secara kontekstual, karena kandungan petunjuk hadisnya tersebut bersifat temporal.
\end{abstract}

Kata Kunci: Hadis; kontekstual; pemimpin; Tekstual; Wanita.

\section{PENDAHULUAN}

Hadis digolongkan sebagai segala sesuatu yang dikaitkan kepada Rasulullah SAW baik dari segi perkataan, perbuatan, sifat dan takrir (penetapan). Selain itu juga merupakan sumber atau pedoman kedua setelah Alquran bagi umat Islam (Ya'qub, 2014). Pada masa Rasulullah SAW hadis belum dibukukan dan ditulis secara resmi. Sebab pada waktu itu hadis masih diajarkan dan diriwayatkan secara lisan dan

*Corresponding Author

Received: December 22, 2020; Revised: February 08, 2021; Accepted: February 08, 2021 
Khazanah Theologia, Vol. 3 No. 2 (2021): 81-92

Hadis Tentang Wanita Menjadi Pemimpin: Menelisik Antara Pemahaman Tekstual dan Kontekstual Perspektif M. Syuhudi Ismail

Ummi Kalsum Hasibuan dan Hafizzullah Hafizzullah.

hafalan. Meskipun demikian tidak menutup kemungkinan adanya beberapa sahabat yang menuliskan hadis untuk kebutuhan pribadi.

Seiring berjalannya waktu, perkembangan hadis terus berlanjut dari masa ke masa. Yang mana proses pembukuan hadis tersebut dipelopori oleh khalifah Umar bin Abdul Aziz yang kemudian menjadikannya nilai sejarah yang amat penting. Karena pembukuan hadis itu menjadi bukti keberhasilan dalam sejarah perkembangan hadis yang sebelumnya, hadis hanya dijaga dalam bentuk hafalan kemudian dibukukan ke dalam kitab-kitab hadis (Safri, 2014).

Salah seorang tokoh yang sangat berpengaruh dan banyak menekuni hadis dan ilmu hadis adalah Muhammad Syuhudi Ismail merupakan pelopor pentingnya memahami hadis secara tekstual dan kontekstual serta termasuk intelektual yang cukup berpengaruh di Indonesia. Kemudian ketika dalam melakukan pemahaman terhadap suatu hadis sangat diperlukan pemahaman hadis secara tekstual dan kontekstual.

Kajian terdahulu tentang wanita menjadi pemimpin telah banyak dan menjadi suatu problematika yang marak serta tak kunjung tuntas bahasannya. Apalagi jika menelaah kembali persepsi pemahaman terkait wanita menjadi pemimpin. Seperti halnya peneliti sebelumnya Siti Fatimah berkesimpulan dengan menggunakan persepsi pemikiran Fatimah Mernissi dalam memahami kepemimpinan politik wanita (Fatimah, 2009). Penelitian lainnya tentang kepemimpinan perempuan dalam perspektif hukum Islam oleh Humaezah menjelaskan bahwa bolehnya kaum wanita menjadi kepala negara atau kepala pemerintah selama masih menggunakan sistem pemerintahan secara musyawarah dan perempuan yang mampu melaksanakan tugasnya. Selanjutnya hal serupa dengan tulisan Yunahar menyebutkan bahwa tidak terdapatnya ayat yang melarang seorang wanita menjadi pemimpin. Kemudian tulisam Fathurrahman menjelaskan menurut historisnya wanita pernah memimpin pada wilayah publik ketika zaman Nabi dan sahabat saat itu pertengahan kekuasaan Islam sampai turunnya era Dinasti Abbasiyah.

Dari banyaknya topik bahasan mengenai wanita menjadi pemimpin dan memberi pesan akan hal perempuan, sehingga dalam penelitian ini akan melengkapi kajian tersebut dengan mencoba memberikan kacamata yang berbeda tentang kepemimpinan wanita baik di ranah domestik maupun publik ditelisik dalam pemahaman tekstual dan kontekstual dari Syuhudi Ismail. Kemudian kajian mengenai hal perempuan merupakan sebuah kajian yang tidak pernah surut dalam setiap ruang dan waktu. Sekalipun telah berulang-kali dibahas dalam banyak ruang, selalu saja ada upaya penyegaran yang tidak kalah signifikan untuk mengkaji ulang tentang hal tersebut. Hal ini disebabkan oleh sebuah konstruk masyarakat yang seolah menempatkan perempuan dalam posisi minor, dari dahulu hingga sekarang. Oleh karena itu peneliti mencoba menyingkap tentang hadis wanita menjadi pemimpin yang ditinjau dari pemahaman tekstual dan kontekstualnya salah satu tokoh yang sangat berkontribusi dalam bidang hadis,yakni M. Syuhudi Ismail.

\section{METODE PENELITIAN}

Metode penelitian dalam tulisan ini termasuk jenis penelitian kepustakaan (library research) yang bertujuan menghimpun informasi dan data melalui buku, dokumen, catatan, majalah, serta kisah sejarah. Sementara terkait pengumpulan data, penenliti memakai pisau analisis deskriptif-analisis (Muhajir, 1989). Tujuan tulisan ini adalah untuk menyingkap dan mengetahui tentang bagaimana pemahaman hadis wanita menjadi pemimpin dalam tinjauan tekstual dan kontekstual Syuhudi.

Syuhudi Ismail merupakan salah seorang tokoh yang ahli dalam bidang hadis pada era kekinian, sehingga dalam hal ini peneliti mencoba menganalisis pemikirannya terkait dengan persoalan tersebut. 
Khazanah Theologia, Vol. 3 No. 2 (2021): 81-92

Hadis Tentang Wanita Menjadi Pemimpin: Menelisik Antara Pemahaman Tekstual dan Kontekstual Perspektif M. Syuhudi Ismail

Ummi Kalsum Hasibuan dan Hafizzullah Hafizzullah.

Dengan demikian peneliti tertarik untuk melakukan sebuah penelitian yang dikaji lebih dalam tentang hadis wanita menjadi pemimpin ditelisik melalui pemahaman tekstual dan kontekstualnya.

\section{HASIL DAN PEMBAHASAN}

\section{Potret Kehidupan Intelektual M. Syuhudi Ismail}

Dalam berinteraksi sosial, Syuhudi sangat terbuka, artinya bergaul dengan siapa saja tanpa memandang golongan dari apapun itu. Muhammad Syuhudi Ismail, lebih dikenal dengan panggilan Syuhudi Ismail lahir di Rowo Kangkung (Rowo Kangkung adalah sebuah desa yang terletak sekitar $20 \mathrm{~km}$ dari Kab. Lumajang atau sekitar $170 \mathrm{~km}$ sebelah Timur kota Surabaya, Jawa Timur.), Lumajang Jawa Timur bertepatan pada tanggal 23 April 1943 (Ismail, 1991). Ia merupakan putera keempat dari pasangan H. Ismail bin Missin bin Soemoharjo (w. 1994) berasal dari suku Madura dan Sufiyatun binti M. Ja'far (w. 1993) dari suku Jawa (Ismail, 2014). Pada Fase kehidupan remajanya tahun 1965 yang berusia 22 tahun Syuhudi memutuskan untuk menikah dengan Nur Haedah Sanusi yang dikaruniai tiga orang anak. Ketika awal tahun 1972 isterinya meninggal dunia, selanjutnya pada akhir tahun itu pula beliau menikah dengan Habiba Sanusi kakak kandung dari istrinya yang pertama (Anggoro, 2019a).

Intelektual Indonesia yang banyak menekuni bidang hadis dan ilmu hadis adalah Muhammad Syuhudi Ismail yang pemikirannya berkaitan dengan pengembangan kajian hadis banyak dituangkan melalui sejumlah buku yang disusunnya. Ia sangat produktif menulis artikel mengenai hadis di berbagai media, termasuk media surat kabar lokal dan nasional.

Pendidikannya bermula pada Sekolah Rakyat Negeri Sidoarjo ketika berusia 12 tahun. Kemudian melanjutkan di PGAN Malang selama 4 tahun dan lulus pada tahun 1959, selanjutnya ke jenjang pendidikan yang lebih tinggi di PHIN (Pendidikan Hakim Islam Negeri) Yogyakarta dan tamat tahun 1961, lalu Syuhudi melanjutkan studinya lagi pada Fakultas Syari'ah Institut Agama Islam Negeri (IAIN) Sunan Kalijaga yang cabangnya di Makassar (kemudian berubah menjadi IAIN Alauddin Makassar) sebagai sarjana muda tahun 1965. Studinya pun terus berlanjut Pada Fakultas Syari'ah IAIN Alauddin Ujung Pandang tamat 1973. Setelah itu melanjutkan Studi Purna Sarjana (SPN) Yogyakarta tahun 1978/1979. Kemudian pada Program Studi S2 IAIN Syarif Hidayatullah Jakarta selesai tahun 1985 dan program Studi S3 IAIN Syarif Hidayatullah Jakarta dengan menempuh ujian promosi doktor pada 28 November 1987 yang desertasinya berjudul "Kaedah Keshahihan Sanad Hadis (Telaah Kritis dan Tinjauan dengan Pendekatan Ilmu Sejarah) (Fatimah, 2009).

Mengenai pekerjaanya, ia pernah menjadi pegawai Pengadilan Agama Tinggi (Mahkamah Syari'ah Provinsi) tahun 1967-1970, Kepala Bagian Kemahasiswaan dan Alumni IAIN Alauddin tahun 1973-1978 dan sebagai sekretaris Kopertais Wilayah VIII al-Jami'ah IAIN Alauddin tahun 1979-1982 seluruh pekerjaannya itu berlokasi di Ujung Pandang. M. Syuhudi Ismail juga aktif berkiprah dalam bidang pendidikan, terutama dalam kegiatan sebagai staf pengajar di berbagai perguruan Tinggi Islam.

Kemudian terkait dengan karya-karyanya, Muhammad Syuhudi Ismail telah menghasilkan sekitar 164 karya yang terbagi dalam beberapa macam karya, baik itu berwujud buku, artikel dan makalah, esai dan lainnya. Selanjutnya juga terdapat sumbangannya sebanyak 13 judul yang terdapat dalam buku Ensiklopedi Islam. Berikut beberapa hasil karya ilmiah beliau yang akan dicantumkan, yaitu: 
Khazanah Theologia, Vol. 3 No. 2 (2021): 81-92

Hadis Tentang Wanita Menjadi Pemimpin: Menelisik Antara Pemahaman Tekstual dan Kontekstual Perspektif M. Syuhudi Ismail

Ummi Kalsum Hasibuan dan Hafizzullah Hafizzullah.

1. Cara Praktis Mencari Hadis (1991).

2. Metodologi Penelitian Hadis (terbit tahun 1992).

3. Hadis Nabi Menurut Pembela, Pengingkar Dan Pemalsunya (1995).

4. Hadis Nabi Yang Tekstual Dan Kontekstual: Tela'ah Ma'ani al-Hadis Tentang Ajaran Islam Yang Universal, Temporal Dan Lokal (terbit tahun 1984).

5. Kaidah Keshahihan Sanad Hadis: Telaah Kritis Dan Tinjauan Dengan Pendekatan Ilmu Sejarah (1987).

6. Pengantar Ilmu Hadis (tahun 1987).

7. Hadis (Ensiklopedia Islam, Depag, 1985).

8. Sunnah Menurut Para Pengingkarnya Dan Upaya Pelestarian Sunnah Oleh Para Pembelanya (1991).

9. Pelaksanaan Syari'at Islam di Indonesia (skripsi IAIN, TAHUN 1973).

10. Penelaahan Hadis Nabi Sebelum Penggunaan Metode Ijtihad (tahun 1974).

11. Penerapan Arah Kiblat pada Bangunan Masjid (1982)

12. Pemikiran Ibnu Taimiyah tentang Ilmu Falak dan Hisab dalam Kaitannya dengan Pelaksanaan Ibadah (1985).

13. Perkawinan Incest, Adat dan Agama (1983).

14. Asbab an-Nuzul al-Qur'an (1985).

15. Beberapa Hadis Populer dalam Masyarakat (Ismail, 1991).

Kemudian bertepatan pada tanggal 19 November 1995 Muhammad Syuhudi Ismail menghebuskan nafas terakhirnya di Rumah Sakit Cipto Mangunkusumo Jakarta. Lalu jasadnya dimakamkan di pekuburan Islam (Arab), Bontoala, Ujung Pandang tanggal 20 November 1995.

\section{Sekilas Pemahaman Hadis Tekstual dan Kontekstual}

Dalam memahami hadis hal pertama kali dilakukan adalah dengan memperhatikan kepada makna apa adanya dalam sebuah teks tersebut, kata lainnya mencoba menangkap makna asalnya, makna yang disuguhkah oleh teks hadis tersebut, sebelum mengaitkannya dengan konteks pemahaman lain. Seperti yang ditulis oleh M. Ajaj al-Khatib dalam bukunya Ushul al-Hadits menurutnya, pemahaman hadis secara tekstual ialah memahami hadis dengan apa adanya yang tertulis pada teks lafziyah (al-Khatib, 2007). Dengan demikian dapat dikatakan bahwa pemahaman tekstual hadis menekankan kepada analisis teks.

Dari pengertian pemahaman hadis secara tekstual tersebut, maka pemahaman tersebut berfokus pada gramatika dan struktur teks yang menekankan pada teks yang terdapat pemahaman yang membuat teks itu sebagai titik tengah dalam pengkajian hadis dan terkadang mengabaikan konteks dari hadis itu sendiri. Segi lainnya pemahaman tekstual condong menghasilkan makna yang kaku dan tetap terhadap suatu hadis. Sebab suatu teks tidak dipahami lebih luas, sehingga tidak membutuhkan hadis-hadis pendukung lainnya sebagai penopang dalam melakukan analisisnya (Sobari, 2014). Maka pemahaman tekstual adalah pemahaman bertumpu pada makna teks (secara literal) tanpa melihat aspek sosio historis, dimana, kapan, dan mengapa teks tersebut lahir.

Sementara pemahaman secara kontekstual, apabila ditinjau dari segi kebahasan konteks berarti kondisi di mana suatu keadaan itu terjadi (Depdikbud, 2005). Dalam kata lainnya, kontekstual merupakan suatu pernyataan yang kemudian untuk pemaknaannya berkaitan dengan 
Khazanah Theologia, Vol. 3 No. 2 (2021): 81-92

Hadis Tentang Wanita Menjadi Pemimpin: Menelisik Antara Pemahaman Tekstual dan Kontekstual Perspektif M. Syuhudi Ismail

Ummi Kalsum Hasibuan dan Hafizzullah Hafizzullah.

keadaan atau konteks terjadinya. Jadi, pemahaman kontekstual ialah pemahaman yang dilandaskan bukan hanya dari segi kebahasaan, namun juga didasari kepada situasi dan kondisi saat teks tersebut muncul. Melihat kepada aspek-aspek luar teks itu sendiri. Dapat dipahami dengan meninjau kembali kepada asbab al wurud hadis, dilihat dari segi historitas teks, sosio kultural dan lain sebagainya (Khudori, 2014).

Dapat ditarik sebuah kesimpulan bahwa pemahaman kontekstual terhadap suatu hadis yakni memahami hadis dengan melihat sisi-sisi konteks yang berhubungan dengan hadis. Pemahaman hadis dari segi kontekstual biasanya digunakan oleh para cendikiawan hadis atau para pengkaji hadis kontemporer dalam memaknai sebuah hadis, karena banyak hal pada era sekarang ini yang tidak bisa dimaknai hanya dengan pemahaman secara teks saja, namun harus melihat lebih luas dari sisi-sisi kontekstualnya. Oleh sebab itu, banyak juga ditemukan metode-metode pemahaman hadis yang baru. Pemahaman kontekstual bukanlah pemahaman yang baru muncul, akan tetapi telah ada sejak zaman sahabat yang memakai pemahaman kontekstual dalam memahami hadis, bahkan ketika Nabi Muhammad SAW masih hidup saat itu.

Terkait pemahaman secara kontekstual yang telah dilakukan oleh para sahabat Nabi dan Imam Syafi'i, masih dalam kategaori tahapan sederhana. Hal ini menjadi inspirasi bagi para generasi-generasi selanjutnya untuk terus mengembangkan metode-metode pemahaman hadis ini, seperti Yusuf al-Qardhawi dan Imam al-Ghazali. Beliau banyak menulis mengenai pemahaman kontekstual ini. Oleh karena itu metode pemahaman hadis secara kontekstual ini merupakan salah satu metode penting untuk dikaji lebih mendalam (Channa, 2011).

Menurut Syuhudi Ismail, keberadaan hadis Nabi yang mengandung petunjuk secara tekstual dan kontekstual tersebut pada dasarnya tidak terlepas dari kebijaksanaan Nabi di bidang dakwah dan dalam rangka penerapan tahapan-tahapan ajaran Islam. Kebijaksanaan Nabi yang demikian bisa dipahami sebagai petunjuk yang mengandung implikasi pemikiran tentang pentingnya peranan berbagai disiplin pengetahuan, baik yang terjangkau pengembangannya oleh ulama selama ini, maupun yang belum terjangkau (Ismail, 1994). Lebih lanjut Syuhudi menjelaskan, bahwasanya sebuah disiplin ilmu (termasuk Hadits) hendaklah berdialog dengan disiplin ilmu lainnya, yang tentunya bercorak humaniora (kemanusiaan) seperti Sosiologi, Antropologi, Psikologi, dan Sejarah. Hal ini sebagai pola sebuah metode pendekatan memahami ajaran Islam dalam nuansa teks dan konteksnya. Karena pada dasarnya pengetahuan senantiasa berkembang dan heterogenitas dalam setiap sudut problematika kemasyarakatan.

Pemikiran Muhammad Syuhudi Ismail merupakan suatu pemikiran yang mencakup pada prinsip penting dan perlu diperhatikan ketika dalam memahami hadis. Yang mana ia lebih menekankan pada pentingnya membedakan bagaimana memahami hadis secara tepat, baik dipahami secara tekstualis maupun kontekstualis. Dalam hal ini terdapat langkah utama yang harus ditempuh adalah melakukan analisis teks hadis dengan menetapkan bentuk matan hadis yang terdiri atas jami' al-kalim (ungkapan singkat padat makna), tamsil (perumpamaan), bahasa simbolik (ramzi), bahasa percekapan (dialog), ungkapan analogi (qiyasi) dan lain-lain. Selanjutnya juga melibatkan kontek munculnya suatu hadis. Dalam hal ini Syuhudi Ismail membaginya kepada dua bentuk, yaitu: pertama, dilihat dari segi posisi dan fungsi Nabi. Kedua, dari segi situasi dan kondidi dimana suatu hadis itu muncul (Anggoro, 2019b).

Dalam memahami hadis secara tekstual atau harfiah saja tidak cukup. Jika semua dalil agama Islam dipahami secara tekstual semata, maka Islam tidak akan berkembang sampai saat ini. Sebab, Rasulullah 
Khazanah Theologia, Vol. 3 No. 2 (2021): 81-92

Hadis Tentang Wanita Menjadi Pemimpin: Menelisik Antara Pemahaman Tekstual dan Kontekstual Perspektif M. Syuhudi Ismail

Ummi Kalsum Hasibuan dan Hafizzullah Hafizzullah.

saw., bersabda melalui hadis-hadisnya memiliki latar belakang kejadian, atau disebut dengan asbāb alwurủd. Oleh karena itu pemahaman hadis secara tekstual dan kontekstual itu adalah penting.

\section{Hadis Tentang Wanita Mejadi Pemimpin Perspektif Tekstual Dan Kontekstual Muhammad Syuhudi Ismail}

Setelah menjelaskan mengenai pemahaman tekstual dan kontekstual hadis, seyogiyanya dalam melakukan penelitian hadis menggunakan dua pisau analisis tersebut agar mendapatkan pemahaman yang eksis. Khususnya dalam memahami hadis-hadis yang mengangkat isu wanita menjadi pemimpin. Hadis tentang wanita menjadi pemimpin ini diriwayatkan oleh beberapa periwayat hadis, diantaranya; Imam al-Bukhari, Turmudzi, an-Nasa'i dan Imam Ahmad bin Hanbal. Adapun beberapa bunyi redaksi hadis tersebut adalah:

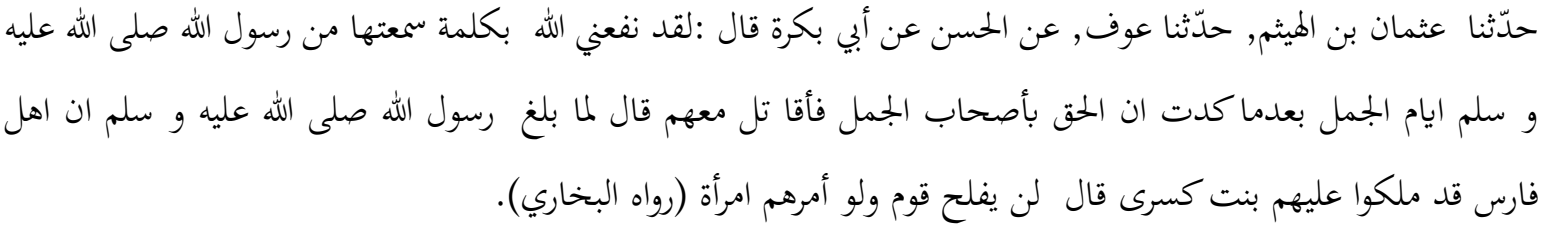

Artinya: Utsman bin Haitsam telah menceritakan kepada kami, Auf telah menceritakan kepada kami, dari Hasan dari Abu Bakar ia berkata: sungguh Allah telah memberi manfaat kepadaku, sebab kalimat yang saya dengar dari Rasulullah SAW pada perang Jamal, ketika saya hampir terjebak ikut dalam perang Jamal selanjutnya ia berkata: ketika berita bahwa Persia telah mengangkat puteri kaisar sebagai ratu, hal tersebut sampai pada Rasul, kemudian beliau bersabda: tidak akan sejahtera suatu bangsa yang menyerahkan segala urusannya kepada wanita. (HR. Al-Bukhari) (Al-Bukhari, 2008).

حدّثنا محمد بن المثنّى, حدّثنا خالد بن الحرث, حدّثنا حميد الطّويل عن الحسن عن أبي بكرة قال :عصمني الله بشيء سمعته من رسول الله صلى الله عليه و سلم لما هلك كسرى قال من استخلفوا قالوا ابنته فقال النّيّ صلى الله عليه و سلم لن يفلح قوم ولو أمرهم امرأة قال فلمّا قدمت عائشة يعني البصرة ذكرت قول رسول الله صلى الله عليه و سلم فعصمني الله به قال أبو عيسى هذا حديث حسن صحيح (رواه الترمزي).

Artinya: Muhammad bin al-Mutsanna telah menceritakan kepada kami, Khalid bin al-Haris telah menceritakan kepada kami, ia berkata Humaid aț-Tawil telah menceritakan kepada kami dari Hasan dari Abu Bakrah berkata: Allah menjagaku dengan sesuatu yang aku dengar dari Rasulullah SAW. Saat Kisra mati, beliau bersabda: "Siapa yang menjadi penggantinya?" mereka menjawab: Putrinya, Rasulullah Saw bersabda: "Tidak akan beruntung suatu kaum yang menguasakan urusan mereka kepada seorang wanitall. Berkata Abu Bakrah: Saat 'Aisyah tiba di Bașrah, aku sebutkan sabda Rasulullah Saw., lalu Allah Swt. menjagaku dengan sabda itu. Berkata Abu Isa: hadis ini hasansaḥih. (HR. AL-Turmudzi)(Al-Turmudzi, 1971)

حَّدنَنَاً يَحيَ عن عيينة حدّثني أبي عن أبي بكرة عن النبيّ صلّى الله عليه وسلّم قال: لن يفلح قوم أسندأمرهم الى امراة (رواه احمد) 
Khazanah Theologia, Vol. 3 No. 2 (2021): 81-92

Hadis Tentang Wanita Menjadi Pemimpin: Menelisik Antara Pemahaman Tekstual dan Kontekstual Perspektif M. Syuhudi Ismail

Ummi Kalsum Hasibuan dan Hafizzullah Hafizzullah.

Artinya: Yahya dari Uyainah telah menceritakan kepada kami, Abi telah menceritakan kepada saya dari Abu Bakrah dari Nabi Muhammad Saw. bersabda tidak akan beruntung suatu kaum yang menyerahkan urusannnya kepada seorang wanita. (HR. Ahmad).

\section{Makna Kata Hadis}

Kata kunci dari matan hadis di atas adalah kalimat لن يفلح dimana "lan" berfungsi sebagai huruf nafi lil-istiqbal, yang menafikan kemungkinan yang akan terjadi. Sementara "فيح" berasal dari fi'il madhi "aflaha" dalam Kamus al-Munawwir berarti berhasil baik (sukses; najah) (Munawwir, 1997) terdiri dari fi'il mudhari' memberikan makna terhadap akan sebuah kesuksesan pada waktu itu dan atau di masa mendatang. Selanjutnya merupakan huruf yang berfungsi untuk menafikan fi'il (perbuatan) di masa akan

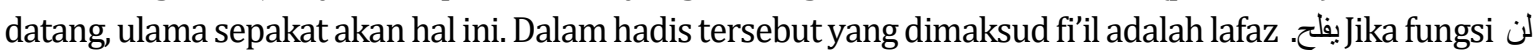
dikaitkan dengan hadis di atas, Namun para ulama' berbeda pendapat mengenai apakah istiqbalnya itu menunjukkan ta'bid (selamanya) atau ta'qit. Jadi pada hadis tersebut, bisa dikatakan bahwa huruf itidak berfungsi ta'bid. Tapi kesimpulan ini masih menimbulkan pertanyaan, yakni terkait dengan hal ta'qitnya. Hal ini bisa dilihat pada pendapat ulama yang melarang perempuan menjadi pemimpin karena perempuan itu lemah daya pikirnya, serta terlalu sempit pemikirannya dikarenakan tidak banyak tahu tentang persoalan masyarakat. Kemudian kalimat " ولو (artinya menguasakan, mempercayakan ataupun

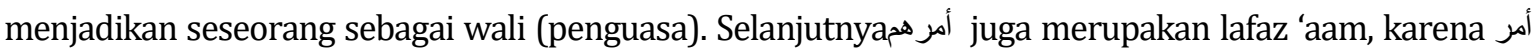
merupakan lafad mufrad yang dimudhafkan pada isim ma'rifta, ini mencakup pada seluruh persoalan.

Kemudian lafaz امر أم adalah muthlaq, dan merupakan salah satu bentuk lafaz khas. Lafad khaas bisa berupa nama seperti Muhammad juga bisa berupa jenis. Sedangkan lafaz امر termasuk lafaz khaas berupa jenis, walaupun berupa jenis, tidak semua nau' tergolong dalam lafaz tersebut. Disebabkan yang dipandang dalam lafaz khaas jenis yakni hakikat atau mahiyah dari lafad dan bukanlah afrad yang ada di dalamnya. Sehingga lafad إمرأ ini tidak bisa mencakup pada seluruh wanita, melainkan hanya pada wanita tertentu saja, sehingga yang dimaksud dalam hadis tersebut adalah anak perempuan Kisra yang didaulat sebagai pengganti ayahnya yang meninggal (Al-Anshari, t.th).

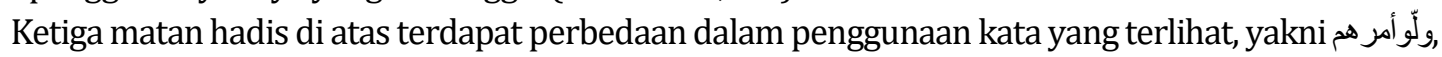
mempunyai arti menyerahkan, menyandarkan, menguasakan urusan. Meskipun terdapat perbedaan redaksi satu sama lain dalam hadis di atas, tidak terdapat pertentangan dari segi makna matan. Secara umum hadis di atas menyampaikan satu hal tentang tidak akan bahagianya suatu kaum apabila dipimpin oleh seorang wanita.

Dalam pemahaman, bahwa yang utama menjadikan hadis ini sebagai dalil tidak dibenarkannya perempuan menjadi pemimpin bagi laki-laki ialah bahwa hadis ini redaksinya berbentuk khabar atau berita, tetapi maknanya adalah insya atau larangan. Artinya Rasul melarang perempuan menjadi pemimpin bagi laki-laki. Dalam hadis ini Rasulullah secara eksplisit menafikan kemenangan dan keberuntungan bagi kaum yang menyerahkan kepemimpinan kepada perempuan. Artinya, jika keberuntungan tidak menyentuh mereka, hanya kemerosotan dan kelemahanlah yang akan ditemui. Di dalam hadis ini memang tidak menggunakan kalimat larangan. Tetapi menggunakan kalimat pengingkaran atau peniadaan keuntungan atau keselamatan bagi suatu kaum yang menjadikan perempuan sebagai pemimpinnya. Kalimat seperti itu tidak menimbulkan adanya larangan terhadap pengangkatan perempuan sebagai pemimpin pemerintah, atau negara, jadi mengangkat perempuan sebagai kepala pemerintah atau negara bukan suatu pelanggaran syariat apabila dilihat dari sejarahnya hadis tersebut. 
Khazanah Theologia, Vol. 3 No. 2 (2021): 81-92

Hadis Tentang Wanita Menjadi Pemimpin: Menelisik Antara Pemahaman Tekstual dan Kontekstual Perspektif M. Syuhudi Ismail

Ummi Kalsum Hasibuan dan Hafizzullah Hafizzullah.

\section{Asbabul Wurud Hadis}

Dalam menyebarkan dakwahnya Rasulullah SAW memiliki berbagai cara untuk pergi ke berbagai daerah dan suatu negara. Seperti dengan cara mengirimkan surat kepada para pembesar kerajaan. Kerajaan yang mendapat surat tersebut adalah Kisra sebagai raja Persia.

Rasulullah SAW mengutus 'Abdullah bin Hudzafah as-Sami untuk mengirimkan surat kepada pembesar Bahrain. Setelah itu pembesar Bahrain menyampaikan surat tersebut kepada Kisra. Setelah membaca surat dari Rasulullah SAW, ia menolak dan bahkan menyobek-nyobek surat Rasul. Lalu peristiwa ini didengar oleh Rasulullah SAW, kemudiam beliau bersabda: "siapa saja yang telah merobekrobek surat saya, dirobek-robek (diri dan kerajaan) orang itu” (Al-'Asqalani \& Al-Bāri, 2003).

Dalam kitab Fath al-bari dijelaskan bahwa ketika Rasulullah mendapat sebuah kabar akan kejatuhan Kisra raja Persia, lalu beliau menanyakan siapa yang menggantikannya. Ketika dijawab oleh anak perempuannya maka Rasulullah SAW bersabda: "Tidak akan beruntung suatu kaum yang diperintah perempuan". Kisra mempunyai nama lengkap Kisra bin Abrawaiz bin Hurmuz, raja Persia. Beliau mempunyai seorang anak laki-laki bernama Syairawaihi. Lalu Syairawaihi memiliki anak perempuan bernama Buwaran. Sebab diangkatnya Buwaran sebagai raja adalah ketika terjadi pemberontakan terhadap Kisra yang dipimpin oleh putranya sendiri (Syairawaihi) sampai ia bangkit untuk melawan ayahnya dan membunuhnya, serta merebut kekuasaannya.

Kemudian Syairawaihi pun meninggal dunia, sehingga tidak ada seorang pun saudara laki-lakinya yang menggantikan kedudukannya sebagai raja, karena ia telah membunuh seluruh saudara laki-lakinya tersebut yang dilandaskan pada ketamakan untuk menguasai tahta kerajaan Persia. Oleh sebab itu tidak ada lah seorang laki-laki yang menjadi pewaris kerajaan serta mereka juga tidak menginginkan kekuasaan kerajaan jatuh kepada pihak lainnya. Maka dari itulah mereka mengangkat seorang wanita bernama Buwaran, yang merupakan anak dari Syairawaihi dan cucu dari Kisra (Al-'Asqalani \& Al-Bāri, 2003).

\section{Pemahaman tekstual hadis wanita menjadi pemimpin}

Secara umum, jumhur ulama dan M. Syuhudi Ismail memahami hadis tersebut hanya dipahami secara tekstual. Berpendapat bahwa atas dasar petunjuk dalam hadis tersebut, terkait pengangkatan wanita menjadi kepala negara, hakim pengadilan dinyatakan bahwa wanita menurut petunjuk syara' tersebut hanya sekedar diberi tanggung jawab untuk menjaga harta suaminya. Dalam memahami hadis perlunya mengkaji terlebih dahulu terkait dengan keadaan yang sedang berkembang ketika hadis itu disabdakan oleh Nabi. Hadis tersebut disabdakan tatkala mendengar tentang penjelasan sahabat beliau terkait pengangkatan wanita menjadi ratu di Persia pada tahun $9 \mathrm{H}$.

Menurut tradisinya yang berlangsung di Persia sebelum itu, yang diangkat sebagai kepala negara adalah seorang laki-laki terjadi pada tahun $9 \mathrm{H}$, lalu hal itu menyalahi tradisi tersebut. sehingga yang menjadi kepala negara bukanlah seorang laki-laki melainkan sseorang wanita, adalah Buwaran. Ia diangkat sebagai ratu di Persia setelah terjadinya pembunuhan-pembunuhan dalam rangka suksesi kepala negara. Kemudian pada saat itu derajat kaum wanita dalam masyarakat tersebut berada di bawah derajatnya kaum laki-laki. Sehingga wanita sama sekali tidak dipercaya dalam ikut serta mengurus kepentingan masyarakat umum, lebihnya lagi dalam urusan kenegaraan. Dalam hal tersebut hanya lakilaki yang dianggap mampu mengurus kepentingan masyarakat dan negara. Hal demikian tidak terjadi semata di Persia saja, melainkan juga di Jazirah Arab. Islam muncul dalam rangka mengubah nasib kaum wanita dengan memberi berbagai hak, kehormatan dan kewajiban terhadap Islam sesuai dengan 
Khazanah Theologia, Vol. 3 No. 2 (2021): 81-92

Hadis Tentang Wanita Menjadi Pemimpin: Menelisik Antara Pemahaman Tekstual dan Kontekstual Perspektif M. Syuhudi Ismail

Ummi Kalsum Hasibuan dan Hafizzullah Hafizzullah.

martabat dan harkat mereka sebagai makhluk yang bertanggung jawab di hadapan Allah, baik itu terhadap diri sendiri, keluarga, masyarakat maupun negara.

Dalam kondisi kerajaan Persia dan masyarakatnya, maka Nabi mempunyai suatu kearifan yang tinggi dan menyatakan bahwa bangsa yang menyerahkan urusan-urusan mereka kepada wanita tidak akan sukses, apabila yang memimpin itu adalah makhluk yang sama sekali tidak dihargai oleh masyarakat yang dipimpinnya. Sebagai syarat yang harus dimiliki sebagai seorang pemimpin adalah kewibawaan. Namun pada saat itu wanita masih belum mempunyai kewibawaan sama sekali untuk menjadi pemimpin masyarakat (Ismail, 1994).

Hadis tersebut jika dilihat pemahaman makna tekstualnya, sangat jelas larangan keras bagi kepemimpinan wanita dalam urusan umum dan pada saat itu wanita sama sekali tidak memiliki sifat kewibawaan untuk menjadi pemimpin masyarakat. Sehingga, mayoritas ulama secara tegas menyatakan kepemimpinan perempuan dalam urusan umum dilarang. Hadis ini merupakan bentuk reinterpretasi dari hadis yang disebutkan Rasulullah saw., ketika mendoakan kerajaan Persia hancur. Hadis diatas menceritakan bentuk protes Abi Bakrah yang mengikuti perang Jamal yang di pimpin oleh Aisyah ra. Hadis ini merupakan bentuk protes atas kepemimpinan Aisyah pada perang jamal tersebut. Berdasarkan hal ini, disebutkan kembali Abi Bakrah hadis yang telah disebutkan oleh Rasulullah jauh sebelum perang Jamal itu terjadi, yaitu ketika terjadinya penolakan kerajaan Persia terhadap ajakannya untuk memeluk agama Islam hingga kehancuran dan diangkatnya ratu Kisra menjadi seorang ratu. Hadis inilah yang digunakan sebagian orang untuk membatasi kontribusi perempuan dalam peran sosial.

\section{Pemahaman kontekstual hadis wanita menjadi pemimpin}

Pemahaman hadis secara tekstual di atas perlu diimbangi dengan pemahaman kontekstual hadis dan asbab al-wurud, karena tidak semua kepemimpinan wanita akan hancur sebagaimana yang disebutkan dalam hadis tersebut. Sungguh sangat tidak mungkin Alquran, hadis, dan fakta bertentangan. Ringkasnya hadis tersebut perlu dianalisis kembali secara tekstual dan kontekstualnya.

Secara umum apabila ditinjau dari aspek kualitas hadis riwayat al-Bukhari, al-Turmuzi, dan alNasa'i dan Imam Ahmad tentang wanita menjadi pemimpin kualitasnya adalah shahîh li dzâtihi. Sanadnya memenuhi kaidah keshahihan sanad hadis, yaitu sanadnya bersambung, periwayatnya bersifat tsiqah, dan terhindar dari syudzûdz dan 'illah. Matannya juga memenuhi kaidah keshahihan matan hadis, yakni terhindar dari syudzûdz dan 'illah. Secara kontekstual M. Syuhudi Ismail memberi pemahaman terhadap hadis tersebut yang dapat dipahami bahwa Islam tidak melarang perempuan menduduki suatu jabatan atau menjadi pemimpin dalam urusan umum. Bahkan menjadi kepala negara, dengan syarat sesuai dengan kriteria dan sanggup melaksanakan tugas tersebut. Sehingga dalam sejarahnya, penghargaan masyarakat terhadap kaum wanita semakin meningkat seiring dengan berjalannya waktu dan juga dalam banyak hal. kaum wanita diberi kedudukan yang sama dengan kaum laki-laki. Bahkan al-Quran pun memberi suatu peluang yang sama kepada kaum wanita dan kaum laki-laki untuk melakukan berbagai kebajikan. Dengan keadaan wanita yang telah memiliki kewibawaan dan kemampuan untuk memimpin serta masyarakat pun juga bersedia menerimanya sebagai pemimpin. Maka, tidak ada salahnya apabila wanita itu dipilih maupun diangkat untuk menjadi pemimpin. Oleh karena itu, hadis tersebut harus dipahami secara kontekstual, karena kandungan petunjuknya bersifat temporal (Ismail, 1994).

Selanjutnya dalam hal ini Syuhudi Ismail menganalisis konteks makro pada wilayah Persia ketika itu. Yang mana masyarakatnya masih memandang hanya sebelah mata saja dari wanita dan membatasinya dalam ranah publik. Analisis konteks yang dilakukan Syuhudi adalah, asbab al-wurud dan konteks makro hadis yang berfungsi untuk mengkhususkan hadis bersifat umum, merinci yang bersifat 
Khazanah Theologia, Vol. 3 No. 2 (2021): 81-92

Hadis Tentang Wanita Menjadi Pemimpin: Menelisik Antara Pemahaman Tekstual dan Kontekstual Perspektif M. Syuhudi Ismail

Ummi Kalsum Hasibuan dan Hafizzullah Hafizzullah.

global dan menentukan ada atau tidaknya nasikh-mansukh dalam suatu hadis. Analisis konteks mencakup beberapa segi, yakni segi historis, sosiologis dan antropologis hadis pada ketika itu.

Kemudian terdapat beberapa pendapat ulama, baik ulama klasik maupun kontemporer tentang wanita menjadi pemimpin, di antaranya: Imam Ahmad, Imam Malik, dan Imam Syafi'i berpendapat bahwa wanita tidak berhak untuk menjadi pemimpin, walaupun dalam lingkup yang lebih terbatas. Karena, bagaimanapun menjadi pemimpin, baik dalam hal kekuasaan luas dan terbatas, pada hakikatnya itu sama. Perbedaannya hanya pada wilayah kekuasaannya semata. Padahal, Rasulullâh jelas-jelas melarang seorang wanita menjadi pemimpin. Sedangkan Abu Hanifah, dibolehkannya seorang wanita menjadi hakim, tetapi tidak boleh menjadi hakim dalam perkara pidana (Akhkam \& Fath, 2008).

Al-Ghazali memberikan argumentasinya bahwa perempuan tidak boleh menjadi khlaifah kenegaraan dan kehakiman dengan hujjah hadis yang diriwayatkan oleh Abi Bakrah di ats, penganut ppendapat ini beranggapan bahwa kondisi psikis perempuan membuatnya lemah dalam mengambil keputusan dan kurangnya keleluasaan perempuan untuk beraktifitas kenegaraan, mengingat adanya peran kodrati perempuan sebagai ibu.

Selanjutnya Yusuf al-Qardhawi berpendapat bahwa perempuan boleh memegang kendali kekuasaaan menurut spesialisasi masing-masing, dan ini telah berlaku sepanjang masa. Sehingga dibolehkannya bagi seorang wanita ikut serta dalam berpolitik. Namun ia melarang wanita menjadi pemimpin dalam segala urusan yang umum dengan beberapa alasan, yaitu: pertama Faktor fisik dan naluri, yang mana seorang perempuan diciptakan untuk mengemban tugas keibuan, mengasuh, dan mendidik anak. Kedua, Faktor kodrati. Hal disebabkan perempuan tidak terlalu tepat memangku jabatan dalam urusan umum, karena perubahan fisiknya selalu terjadi karena menstruasi, hamil, melahirkan, dan menyusui anak. Semua ini membuat fisik, psikis dan pemikiran perempuan tidak mampu mengemban tugasnya di luar rumah tangganya (Al-Qardhawi, 1997).

Dalam hal ini Fatima Mernissi melakukan sebuah kritik terhadap hadis ini. Dia mengkritik dari segi sanad dan matannya, yang mana ia mempertanyakan kredibilitas Abû Bakrah sebagai periwayat hadis dan mengapa Abû Bakrah baru memunculkan hadis ini pada saat terjadi kemelut politik dalam perang Jamal antara Âisyah dan Alî bin Abû Thâlib setelah 23 tahun wafatnya Rasulullah SAW, yang mana dirinya berpihak kepada Alî. Lagi pula konteks hadis tersebut tertuju pada kasus suksesi Kisra di Persia yang mewariskan tahta kepada anak perempuannya yang tidak memiliki kapasitas sebagai pemimpin.

\section{Analisis hadis tentang wanita menjadi pemimpin}

Terkait telah berhasilnya Muhammad Syuhudi Ismail menjadi seorang tokoh hadis yang prolific, ensiklopedik dan ijtihadi tidak terlepas dari beberapa sifat yang melekat pada dirinya. Sebagai seorang yang tekun, teguh pendirian, tabah, sabar, istiqamah, disiplin, cerdas, berani, kritis, dan bertanggungjawab. Beliau juga dikenal sebagai seorang yang moderat, dan seorang seorang ahli politik yang mendahulukan kepentingan umat, agama, dan intelektual yang professional, serta mampu menyelesaikan masalahmasalah kemasyarakatan secara kontekstual dan argumentatif. Sementara tantangan yang terbesar bagi pengkaji hadis di Indonesia adalah mencapai aspek tersebut dan mengembangkan ranah baru dalam kajian hadis serta menghasilkan karya dalam bidang hadis yang berdampak langsung kepada masyarakat.

Salah satunya pembahasan tentang wanita menjadi pemimpin, yang mana dalam hal ini Syuhudi Ismail mengkaji pemahaman nya melalui aspek tekstual dan kontekstual. Secara tekstual hadis tersebut memang dipahami sebagai suatu larangan bagi wanita pada saat itu untuk menjadi pemimpin termasuk itu sebagai kepala negara ataupun presiden. Hal ini dikarenakan wanita pada saat itu tidak memiliki kewibawaan untuk menjadi seorang pemimpin masyarakat. Yang mana di dalam Alquran tidak 
Khazanah Theologia, Vol. 3 No. 2 (2021): 81-92

Hadis Tentang Wanita Menjadi Pemimpin: Menelisik Antara Pemahaman Tekstual dan Kontekstual Perspektif M. Syuhudi Ismail

Ummi Kalsum Hasibuan dan Hafizzullah Hafizzullah.

ditemukannya satu dalil pun yang secara eksplisit ataupun spesifik melarang perempuan menjadi kepala negara atau pemimpin. Karena kepemimpinan adalah ajaran Islam yang luas bukan termasuk ibadah mahdiah maka kaedahnya adalah semua boleh kecuali ada kaedah yang melarangnya.

Kepemimpinan seorang perempuan dibolehkan. Dibolehkan bagi perempuan yang mempunyai kekuatan (kelebihan tersendiri) yang ahli dibidangnya. Sama saja dengan seorang laki-laki. Kepemimpinan yang diemban seorang laki-laki sekalipun jika tidak memiliki kemampuan dan kekuatan, maka akan hancur dan merugikan bagi yang dipimpin. Namun, wanita tidak harus berubah warna menjadi "seorang laki-laki" yang tegas dan berwibawa. Sebab, kepemimpinan juga ideal ketika identik dengan kelemah-lembutan dan kasih-sayang (sesuai tabiat perempuan). Oleh karena itu kepemimpinan perempuan yang memiliki ilmu pengetahuan serta keahlian dan kekuatan di bidangnya boleh dijadikan pemimpin. Namun sebaliknya adalah ketika kondisi historis, sosiologis, dan antropologis masyarakat pada saat itu telah berubah, yang mana wanita telah memiliki sikap kewibawaan dan kemampuan memimpin yang baik, lalu masyarakat telah dapat menghargai wanita dengan baik serta menerimanya sebagai pemimpin, maka boleh saja perempuan diangkat menjadi seorang pemimpin. Dalam sejarah, penghargaan masyarakat kepada kaum wanita semakin meningkat, yang pada akhirnya dalam banyak hal. Sehingga kaum wanita diberi kedudukan yang sama dengan kaum laki-laki. Al-Qur'an sendiri memberi peluang sama kepada kaum perempuan dan kaum laki-laki untuk melakukan berbagai amal kebajikan. Dengan demikian, hadis di atas harus dipahami secara kontekstual sebab kandungan petunjuknya bersifat temporal. Maka untuk mencapai pada pemahaman tersebut haruslah ditafsirkan atau dipahami sesuai dengan zaman dan konteks sosio-historisnya saat itu.

Dalam hal ini peneliti berpendapat bahwa hadis wanita menjadi pemimpin itu boleh, karena melihat pada konteks kekinian yang semakin berkembangnya zaman. Bahkan juga banyak wanita yang telah menjadi pemimpin, seperti halnya megawati yang pernah memimpin sebagai presiden Indonesia. Jadi, setiap teks hadis tidak selalu dipahami secara tekstual semata, melainkan perlunya pemahaman kontekstual dengan meninjau ulang sebab turunnya hadis dan juga melihat serta menghubungkan pada konteks kehidupan yang terus progresif seiring berjalannya waktu.

\section{SIMPULAN}

Berdasarkan pembahasan di atas mengenai hadis wanita menjadi pemimpin yang ditinjau dari pemahaman tekstual dan kontekstual. Dapat disimpulkan bahwa pemahaman hadis Syuhudi Ismail secara tekstual bahwa hadis tersebut pada dasarnya memang merupakan suatu larangan wanita menjadi pemimpin dalam urusan umum dan ketika itu wanita belum sama sekali mempunyai sifat kewibawaan. Sedangkan pemahaman secara kontekstual bahwa hadis wanita menjadi pemimpin Syuhudi memahaminya dengan melakukan analisis asbab al-wurud dan konteks makro pada wilayah Persia saat itu. Dengan syarat wanita dalam keadaan telah memiliki kewibawaan, sesuai kriteria dan sanggup melakukan tugasnya dalam memimpin serta masyarakat pun bersedia menerimanya jadi pemimpin. Oleh karena itu hadis tersebut perlunya pemahaman kontekstual, karena kandungan petunjuknya bersifat temporal dan hadis ini dikategorikan oleh Syuhudi Ismail sebagai kelompok hadis yang berkaitan dengan keadaan sedang terjadi (berkembang). 
Khazanah Theologia, Vol. 3 No. 2 (2021): 81-92

Hadis Tentang Wanita Menjadi Pemimpin: Menelisik Antara Pemahaman Tekstual dan Kontekstual Perspektif M. Syuhudi Ismail

Ummi Kalsum Hasibuan dan Hafizzullah Hafizzullah.

\section{REFERENSI}

Akhkam, I., \& Fath, T. A. (2008). Kitabul Aiman wan-Nadar. Beirut: Darul Alamiyyah.

Al-'Asqalani, I. H., \& Al-Bāri, F. (2003). Syarh Shahih al-Bukhari, Juz VIII. Libanon: Dar al-Kutub alIlmiyah.

Al-Bukhari, I. A. 'Abdullah M. ibn I. ibn I. ibn B. A.-J. (2008). Shahih Bukhari. Jakarta: Maktabah al-Shafa. al-Khatib, M. A. (2007). Ushul al-Hadis, Pokok-pokok Ilmu Hadis. Jakarta: Gaya Media Pratama.

Al-Qardhawi, Y. (1997). Fiqih Daulah Perspektif alQur'an dan Sunnah. Jakarta: Pustaka al-Kautsar.

Al-Turmudzi, A. 'Isa M. bin 'Isa bin S. (1971). Sunan at-Turmudzi. Beirut: Dar al-Kutb al-'Ilmiyyah.

Anggoro, T. (2019a). Analisis Pemikiran Muhammad Syuhudi Ismail Dalam Memahami Hadis. Diroyah: Jurnal Studi Ilmu Hadis, 3(2), 94-104.

Anggoro, T. (2019b). Studi Hadis di Indonesia: Kajian Atas Hermeneutika Hadis Muhammad Syuhudi Ismail. UIN Sunan Kalijaga Yogyakarta.

Channa, L. (2011). Memaknai Hadis Secara Tekstual dan Kontekstual. Ulumuna Journal of Islamic Studies, 15(2).

Depdikbud. (2005). Kamus Besar Bahasa Indonesia. Jakarta: Balai Pustaka.

Fatimah, S. (2009). Metode Pemahaman Hadis Nabi Dengan Mempertimbangkan Asbabul Wurud (Studi Komparasi Pemikiran Yusufal-Qardhawi dan M. Syuhudi Ismail). UIN Sunan Kalijaga.

Ismail, M. S. (1991). Pengantar Ilmu Hadis. Bandung: Angkasa.

Ismail, M. S. (1994). Hadis Nabi Yang Tekstual dan Kontekstual (Telaah Ma'ani al-Hadis tentang Ajaran Islam yang Universal, Temporal, dan Lokal). Jakarta: Bulan Bintang.

Ismail, M. S. (2014). Kaedah Keshahihan Sanad Hadis (Telaah Kritis Dan Tinjauan Dengan Pendekatan Ilmu Sejarah). Jakarta: Bulan Bintang.

Khudori, M. (2014). Pentingnya Memahami Hadis Secara Tekstual dan Kontekstual. The 3rd Annual Malang International Peace Conference.

Muhajir, N. (1989). Metodologi Penelitian Kualitatif Edisi IV. Yogyakarta: Raka Sarasin.

Munawwir, A. . (1997). Kamus al-Munawwir. Surabaya: Pustaka Progresif.

Safri, E. (2014). Metode Takhrij al-Hadis. Padang: Hayfa Press.

Sobari, A. (2014). Method Understanding The Hadith. Jurnal Syariah Mizan, 2(2).

Ya'qub, A. M. (2014). Cara Benar Memahami Hadis. Jakarta: Pustaka Firdaus. 